\title{
Research on the Influence of MOOC Teaching on the Reform of Ideological and Political Education in Colleges and Universities
}

\author{
Meng Shao \\ Nanyang Institute of Technology, Nanyang, Henan 473000, China
}

Keywords: MOOC; Colleges and Universities; Ideological and Political; Teaching Reform

\begin{abstract}
MOOC is a large-scale online open course. It is a brand-new teaching form that connects the Internet with teaching activities based on network technology. Compared with traditional teaching methods, MOOC has the characteristics of large-scale, online and open. The course is based on network technology, so the spatial location is no longer the main factor limiting the classroom capacity. A course of up to 100,000 students can be online at the same time. Throughout the process, teachers and students communicate and communicate through the Internet to complete homework and assessment. Learning results and even issuing assessment certificates have greatly improved the efficiency of teaching; teachers and students are engaged in teaching activities under an open condition, and anyone, any time, anywhere can participate in the class. It can be said that MOOC is a major reform in the field of teaching. As a typical representative of public foundation courses in colleges and universities, the traditional ideological and political courses are still based on classroom teaching. In the mode of MOOC, teachers in the ideological and political teaching activities are positioned as for the disseminators of teaching content, the main teaching objectives should also emphasize the motivation of students to learn and cultivate students' learning methods. Therefore, the ideological and political teaching activities based on MOOCs emphasize the cultivation of students' self-learning ability. Based on this, the paper discusses the influence of MOOC teaching on the reform of ideological and political teaching in colleges and universities.
\end{abstract}

\section{The Significance of Applying MOOC in College Ideological and Political Courses}

Specifically, the significance of applying MOOCs in colleges and universities is mainly reflected in the following aspects:

The teaching of ideological and political courses is mainly to systematically educate college students on Marxist theory. The teaching effect of ideological and political courses will have an important impact on the quality of national talent training, which directly affects students' moral quality and comprehensive quality. The MOOC has the characteristics of large scale, openness and linearity. It provides a new way of thinking for the teaching of ideological and political courses in colleges and universities, and expands the teaching carrier of ideological and political courses. Students can receive party education at any time and through the network. Compared with traditional infusion teaching, it is obvious that the MOOC is more attractive to students.

Compared with other disciplines, the political and ideological politics of college ideological and political courses is relatively strong. It is mainly aimed at the education of students' ideology. The main purpose is to improve students' political consciousness, which is different from ordinary pure knowledge courses. At this stage, most of the ideological and political professors in colleges and universities are mostly limited to the classroom and cannot meet the basic requirements of Marxist popular education. The emergence of the MOOC is very good for this deficiency. Different learners can participate in it, providing a platform for the high-minded people to enhance the party spirit and greatly improve the popularization rate of the ideological and political curriculum.

In the traditional ideological and political classroom, the indoctrinating teaching mode is adopted. The students are in the passive position of learning, which not only has low enthusiasm for learning, but also has poor learning effect. The application of MOOC is a great innovation in the ideological and political curriculum. During the teaching process, the teacher re-examines the teaching process, reorganizes the process and results, the relationship between knowledge and ability, means and 
purpose in the process of ideological and political teaching, and focuses on cultivating students' learning ability. , thinking ability and practical ability, enhance students' sense of responsibility, help them establish a correct outlook on life, values, world view. In addition, the application of MOOC also sets an equal teaching philosophy. Students have more room for opinions. Students and teachers can exchange roles in the classroom. Teachers play the role of guides and supporters throughout the teaching process. They must not only respect the active thinking needs of students, but also serve students.

\section{The Influence of MOOC Teaching on Ideological and Political Courses}

The application of motto in college ideological and political education should also be guided by Marxist theory, supplement social hotspots and typical cases, and combine the excellent traditional culture and socialist values to deeply optimize the content of ideological and political motto. First of all, the classroom teaching adheres to the problem-oriented, combining the ideological and political curriculum with the students' actual life, which not only is closer to the student's life, but also can further improve the pertinence of the ideological and political curriculum and strengthen the students' understanding of the ideological and political content. Second, it is based on traditional culture. Ideological and political teaching itself has a strong political color of ideological politics. It bears the important responsibility of carrying forward the national spirit and educates students on patriotism, collectivism, and socialism. Through the form of MOOC, students can be better enhanced. The sense of identity with mainstream ideology education further enhances its sense of mission and social responsibility. Finally, enrich the content of the class by making micro-videos. You can upload the details and fragments of your daily life into small videos and upload them to the platform of the MOOC. For example, some touching stories, charity activities, good deeds, etc., let the students deeply understand the power of the example and help them establish a correct outlook on life and values. The world view, through the MOOC, enhances the fresh vitality and competitiveness of the ideological and political curriculum.

The first is to fully realize online teaching. The MOOC is based on information technology as its carrier. Therefore, network teaching is an inevitable means of ideological and political curriculum teaching in the field of MOOC. Teachers should change the traditional classroom teaching form, combine online teaching and micro-video teaching to realize the seamless connection between the Internet and the teaching classroom, and give full play to the advantages of information technology. Colleges and universities should provide more convenient conditions for the teaching of MOOC, such as establishing an online teaching platform, creating a network courseware database, and so on. Teachers need to carefully craft a large number of online micro-video courses, upload them to the learning platform, and arrange their own learning time for independent learning, which greatly improves the mobility of ideological and political learning; pay attention to the in-depth analysis of teaching quality in the production of online micro-video courses. Clarify the key points and difficulties of each lesson, and combine the advanced teaching methods such as problem teaching method, situational teaching method and case analysis method to help students accurately understand the teaching materials. The network can also be used as a tool for teachers and students to communicate daily, such as WeChat, QQ, Weibo, forums, etc. Teachers and students can communicate and communicate anytime and anywhere through online social tools to help students solve their doubts. Under the field of MOOC, the teaching methods of virtual classrooms are more free, and the barrier-free communication between teachers and students is realized, so better teaching results can be achieved.

On the other hand, it can be used for thematic teaching of ideological and political courses, that is, based on the teaching materials, the teaching content is integrated, refined and summarized. The whole process is not restricted by the textbooks, festivals and purposes, and the logical relationship and center of the course content are defined. In the actual teaching activities, the teacher should do an artistic classroom introduction, clarify the teaching objectives and teaching priorities of the special teaching, display the teaching content through diversified teaching methods, and finally summarize the teaching topics. The whole process guides students to volunteer and consciously. 
Independently participate in the study of ideological and political courses to stimulate their initiative.

Traditional classroom teaching pays more attention to the results assessment. For the teacher's assessment, the teaching time and the amount of scientific research do not evaluate the teacher's teaching process. Therefore, the teacher who is welcomed by the students in actual teaching does not match the proportion of the large faculty. Although most teachers have high education and high quality, because the college teacher evaluation system is not scientific, the teacher's teaching process is not objectively evaluated. How to use the new technology and new methods to cultivate students' innovative thinking in the teaching process? Evaluation is also very lacking, so the evaluation of teachers' teaching ability is not comprehensive and objective. Under the vision of the MOOC, teachers must innovate the design planning and teaching methods of the teaching process, and do a good job of pre-class investment and preparation in order to better adapt to the teaching form of MOOC. In response to this situation, the school must establish a scientific evaluation system, not only to evaluate the teacher's teaching results, but also to comprehensively evaluate its teaching service awareness, teaching design quality, etc.; establish a fair and just public incentive mechanism, through material incentives, spiritual incentives, etc. Means give teachers more encouragement and create a good teaching atmosphere. Finally, we must choose a scientific evaluation method to comprehensively and comprehensively evaluate teachers from the school, off-campus, and society to ensure the objectivity and impartiality of the assessment results.

\section{The Considerations of the Application of MOOC in Ideological and Political Teaching}

Although MOOC has an irreplaceable advantage, it is not a panacea as a teaching method. In the actual teaching process, we should pay attention to the following two aspects: On the one hand, we must pay attention to the mixed teaching mode to match the essence of ideological and political curriculum teaching. . The teaching purpose of the ideological and political course is Lide Shuren. This is contrary to the openness, sharing and individuality of the MOOC. Therefore, the application of MOOC in ideological and political teaching should avoid absolute and dogmatic. It gives full play to the technical advantages of MOOCs to solve the shortcomings of traditional teaching methods, but also to maintain rationality, and not to "move classes" for "move classes", so as not to take the initiative. In the teaching process, the teaching rules of the ideological and political curriculum should be fully followed, so that the MOOC and the traditional teaching methods are combined to form complementary advantages to meet the more diversified needs of the students. On the other hand, it is necessary to dialectically consider the influence of MOOC on the teaching of ideological and political courses. In a certain sense, MOOC is an exotic product. It originated from the United States, which has a great difference from China's education system. There must be some inherent insufficiency in the integration of China's traditional curriculum system. Therefore, its teaching of ideological and political courses the impact is also double. It is not only a useful supplement to the traditional classroom, but also innovates the teaching methods of the traditional ideological and political curriculum, and also brings some negative effects to the traditional ideological and political classroom teaching. Mu Xueyi leads to the flow of ideological and political curriculum in the form, which increases the risk of homogenization, which directly affects the stability of the ideological and political curriculum teachers. Therefore, in the ideological and political curriculum, the application of the motto should deal with the relationship between the two, to avoid risks to the greatest extent, and truly complement each other.

\section{Conclusion}

It can be said that the emergence of the MOOC is the progress of the times, and it is the reform of the traditional teaching mode. It is of great significance to the teaching of open courses in colleges and universities. In particular, the application of the motto in the ideological and political curriculum expands the teaching carrier of the ideological and political curriculum and expands the ideological politics. The dissemination rate of the curriculum has also changed the teaching concept 
of teachers and students. Therefore, the MOOC and the ideological and political classroom teaching rules are consistent, so better results can be achieved. In the field of MOOC, the teacher is equal to the students in the pre-class explanation or the in-class inquiry, or the students are in an equal position. The students take the initiative to participate and change the passive acceptance of the traditional teaching, which greatly improves the students. In addition, MOOC can also improve the pertinence of ideological and political courses. The combination of MOOC and classroom teaching complements each other's advantages, reduces the abstract empty teaching, introduces practical and hot issues in the society into the classroom, and combines information technology to teach. Further expand the teaching space; of course, in practical application, we should pay attention to the organic combination of the MOOC and the traditional teaching mode, so that it is more suitable for the essence of ideological and political curriculum teaching, and the influence of the MOOC on the teaching of ideological and political courses. In summary, the application of MOOCs in the teaching of ideological and political courses is of great significance for improving classroom teaching efficiency and improving classroom effectiveness.

\section{References}

[1] Ma Qiuli. Analysis on the Risks and Avoiding Strategies of Introducing MOOC in College Ideological and Political Theory Courses[J].Journal of Ideological Theory Education, 2016,(3): 123-126.

[2] Zhou Chunpeng. The Influence of Western Ideological Trends on Ideological and Political Theory Courses in Colleges and Universities and Countermeasures [J].Net Wealth, 2010, (21):20-21.

[3] Luo Fangfang, Guan Xinru. The Influence of "Mu Class" on the Open Teaching Mode of Ideological and Political Theory Courses [J]. Journal of Hetian Teachers College, 2015, (4): 43-46.

[4] He Chunyang. Theoretical Exploration of College Ideological and Political Education under the Network Environment [J]. School Party Construction and Ideological Education, 2014, (12): 80-82.

[5] Gu Yumin. The "Cold Thinking" after the Reform of the Ideological and Political Theory Course in Colleges and Universities after the "Mu School Hot"[J].Journal of Ideological and Theoretical Education,2016(1):115-117.

[6] Deng Wei. Promote the reform and innovation of teaching mode, and improve the pertinence and effectiveness of ideological and political courses [J]. China Higher Education, 2015(21): 18-20.118 